Info Artikel:

\title{
Peluang dan Tantangan Bimbingan Karir di Sekolah Menengah Kejuruan Pada Era Revolusi Industri 4.0
}

\author{
Rima Pratiwi Fadli ${ }^{1}$, Mudjiran ${ }^{2}$, Ifdil Ifdil ${ }^{3}$, Berru Amalianita ${ }^{4}$ \\ ${ }^{1234}$ Universitas Negeri Padang
}

\begin{abstract}
The 4.0 industrial revolution brought various changes in various fields of life especially related to the development of individual careers. This development has positive and negative impacts that create opportunities and challenges. This has become material for BK / Counselor teachers, especially in the implementation of career guidance in schools. The following will be explained related to the opportunities and challenges of career guidance in vocational high schools in the industrial revolution era 4.0. This paper was written using a literature study of various references related to the topics discussed. Reference literature in this manuscript is from textbooks, scientific journals of research results, online proceedings, and other supporting literature.
\end{abstract}

Keywords: (vocational guidance, career, indsutrial revolution 4.0)

\section{PENDAHULUAN}

Pertumbuhan ekonomi semakin menurun sehingga menimbulkan peningkatan jumlah pengangguran di Indonesia (Anshori, 2018). Indonesia mempunyai angka pengangguran terdidik yang terus bertambah tiap tahunnya (Maryati, 2015) dan berada pada kategori tinggi (Supardi, 2015; Wibowo, 2016). Perkembangan ilmu pengetahuan dan teknologi juga membawa berbagai perubahan dikalangan masyarakat. Individu dengan adanya perkembangan teknologi pada era revolusi industri 4.0 ini menuntut individu untuk melek teknologi berbasis digital. Salah satu yang ikut mengalami perubahan pada era revolusi industri 4.0 ini adalah perkembangan karir individu.

Karier adalah suatu proses yang harus melalui perencanaan dan melalui seleksi yang cukup panjang. Setiap individu dapat melakukan perencanaan yang tepat namun kadang kala perjalanan seseorang dapat mengubah perjalanan karier seseorang. Gibson \& Mitchell mendefinisikan karier (career) sebagai perjalanan pengalaman 
kerja seseorang di dalam kategori pekerjaan (Gibson \& Mitchell, 2011). Pada era revolusi industri 4.0 ini, perkembangan karir individu memiliki peluang dan tantangan. Tantangan yang dihadapi individu dapat terkait dengan berbagai permasalahan karir yang ada saat ini. Permasalahan tersebut diantaranya: (1) beban memiliki pemahaman yang mantap tentang kelanjutan pendidikan setelah lulus, (2) program studi yang dimasuki bukan pilihan sendiri, (3) belum memahami jenis pekerjaan yang cocok dengan kemampuan sendiri, (4) masih bingung untuk memlih jenis pekerjaan yang sesuai dengan minat dan kemampuan, (5) merasa pesimis bahwa setelah lulus akan mendapatkan pekerjaan yang diharapkan (Angelina, 2018). Selanjutnya berdasarkan hasil juga ditemukan bahwa persepsi siswa tentang kesesuaian perencanaan arah karir dengan pilihan keahliannya di sekolah menengah kejuruan masih berada dalam kategori cukup (Fadli, Alizamar, \& Afdal, 2017). Artinya bahwa persepsi siswa akan pentingnya kesesuaian pilihan keahliannya dengan rencana arah karirnya masih perlu untuk ditingkatkan. Permasalahan-permasalahan karir tersebut jika dianalisis dari teori perkembangan karir Super diawali dengan adanya permasalahan pada tahap orientasi karir.

Orientasi karir di sekolah sangat diperlukan untuk membantu siswa mengenali diri, pekerjaan dan lingkungan kerja (Marwiyah, 2012) yang akan dihadapinya di dunia kerja khususnya terhadap siswa sekolah menengah kejuruan (Juwitaningrum, 2013). Orientasi tersebut dilaksanakan melalui bimbingan karir oleh guru BK/Konselor. Bimbingan karir perlu diberikan kepada siswa untuk menyaring serta menyeleksi potensi-potensi yang dimilikinya atau potensi-potensi yang sesuai yang dimiliki oleh para siswa dalam menentukan pilihannya untuk mewujudkan dirinya pada pekerjaan, jabatan atau karir yang tersedia (Sukardi, 1987). Berdasarkan pemaparan diatas dapat diartikan bahwa pendidikan khususnya di sekolah berperan dalam membantu siswa dalam menghadapi tantangan karir di era revolusi industri 4.0 ini.

Era Revolusi Industri 4.0 diiringi dengan berbagai perubahan (Nofrion, 2018). Ada jenis-jenis pekerjaan tertentu yang akan hilang karena proses otomasi dan digitalisasi (Angelina, 2018). Sekolah perlu membekali para siswa dengan keterampilan yang sesuai. Begitupun dengan peserta didik, perlu membekali peserta didik dengan keterampilan juga karir yang sesuai dengan bakat dan minatnya. Hal demikian juga didukung oleh tujuan dari pendidikan kejuruan. Undang-Undang Sistem Pendidikan Nasional Nomor 20 Tahun 2003 menjelaskan bahwa pendidikan kejuruan merupakan memiliki kedudukan dan peranan penting dalam fungsi menyiapkan tenaga kerja terampil untuk menunjang Sistem Pendidikan Nasional (Indonesia, 2003). Pendidikan kejuruan juga merupakan pendidikan yang mempersiapkan siswa untuk dapat bekerja dalam bidang tertentu. Hal demikian bermakna bahwa sangat penting peran dari pihak sekolah khususnya guru BK/Konselor dalam membantu mewujudkan tujuan pendidikan sekolah kejuruan tersebut.

Perwujudan tersebut dapat dilakukan dengan kegiatan bimbingan karir yang ada disekolah. Kegiatan bimbingan karir menitikberatkan kepada perencanaan kehidpan, yang terlebih dahulu haruslah mempertimbangkan potensi-potensi diri yang dimilikinya serta lingkungan sekitar agar mereka memperoleh dan memiliki pandangan yang cukup luas dari pengaruh terhadap berbagai peranan positif yang layak dilaksanakan dalam masyarakat (Sukardi, 1987). Bimbingan karir merupakan salah satu pelaksanaan dari enam bidang bimbingan dan konseling. Peluang dan tantangan pelaksanaan bimbingan karir pada era revolusi industri 4.0 sangat penting dicermati oleh guru BK/konselor. apabila guru BK/konselor mampu untuk mengadapi peluang dan tantangan ini maka pelaksanaan bimbingan dan konseling di sekolah dapat berjalan lebih optimal dan eksis di kalangan masyarakat sekolah khususnya sekolah menengah kejuruan.

\section{PEMBAHASAN}

\section{Revolusi Industri 4.0}

Revolusi industri 4.0 telah mengubah hidup dan kerja manusia secara fundamental. Berbeda dengan revolusi industri sebelumnya, revolusi industri generasi ke-4 ini memiliki skala, ruang lingkup dan kompleksitas yang lebih luas. Kemajuan teknologi baru yang mengintegrasikan dunia fisik, digital dan biologis telah mempengaruhi semua disiplin ilmu, ekonomi, industri dan pemerintah. Bidang-bidang yang mengalami terobosoan berkat kemajuan teknologi baru diantaranya (1) robot kecerdasan buatan (artificial intelligence robotic), (2) teknologi nano, (3) bioteknologi, dan (4) teknologi komputer kuantum, (5) blockchain (seperti bitcoin), (6) teknologi berbasis internet, dan (7) printer 3D (Schwab, 2017).

Industri 4.0 merupakan nama tren otomasi dan pertukaran data terkini dalam teknologi pabrik. Istilah ini mencakup sistem siber-fisik, internet untuk segala, komputasi awan, dan komputasi kognitif (Hermann, Pentek, \& Otto, 2016; Jasperneite, 2012; Kagermann, Helbig, Hellinger, \& Wahlster, 2013; Lasi, Fettke, Kemper, Feld, \& Hoffmann, 2014). Revolusi Industri adalah periode industrialisasi besar yang terjadi selama akhir 1700-an dan awal 1800-an. Revolusi Industri dimulai di Britania Raya dan dengan cepat menyebar ke seluruh dunia; 
Revolusi Industri Amerika, yang biasa disebut Revolusi Industri kedua, dimulai antara 1820 dan 1870. Periode ini melihat mekanisasi pertanian dan manufaktur tekstil dan revolusi dalam kekuasaan, termasuk kapal uap dan rel kereta api, yang berdampak sosial, budaya dan kondisi perekonomian.

Revolusi industri 4.0 merupakan fase keempat dari perjalanan sejarah revolusi industri (Muhammad, 2018) yang dimulai pada abad ke -18. Menurut Prof Schwab, dunia mengalami empat revolusi industri. Revolusi industri 1.0 ditandai dengan penemuan mesin uap untuk mendukung mesin produksi, kereta api dan kapal layar. Berbagai peralatan kerja yang semula bergantung pada tenaga manusia dan hewan kemudian digantikan dengan tenaga mesin uap. Dampaknya, produksi dapat dilipatgandakan dan didistribusikan ke berbagai wilayah secara lebih masif. Namun demikian, revolusi industri ini juga menimbulkan dampak negatif dalam bentuk pengangguran masal (Schwab, 2017).

Pendidikan Indonesia diharapkan dapat menghasilkan lulusan yang berkompeten (Hakim, 2010), berkarakter dan inovatif demi kemajuan dan peningkatan kualitas sumber daya manusia dalam negeri. Oleh karena itu, persaingan di dunia kerja setelah peserta didik maupun mahasiswa lulus dari sekolah dan universitas akan semakin berat karena pada era industri 4.0 ini juga terdapat kecerdasan buatan seperti robot yang saat ini sudah sangat banyak dimanfaatkan oleh industri demi mencapai tujuan produksi dengan mengurangi biaya tenaga kerja dengan bukti nyata pada kasus PHK pada tahun 2017 yang mencapai 9. 822 orang di Indonesia. Dapat di katakan begitu karena tentu saja kecerdasan buatan di bidang industri dapat lebih meningkatkan kualitas produksi yang stabil dan memperbanyak produksi yang dihasilkan (Angelina, 2018).

Akibat lain dari adanya kecerdasan buatan yaitu menipisnya kesempatan kerja bagi lulusan-lulusan baru jika lulusan-lulusan ini tidak dapat memanfaatkan teknologi yang berkembang pada era saat ini, tetapi bukan tidak mungkin hal ini menjadi peluang yang besar demi meningkatkan kualitas sumber daya manusia dan juga meningkatkan ekonomi negara. Maka dari itu, segala hal yang berkaitan dengan perkembangan teknologi pada era industri 4.0 ini harus bisa diikuti ataupun dimanfaatkan oleh mahasiswa maupun peserta didik yang masih menempuh pendidikan. Peserta didik juga harus lebih serius dalam mengimbangi perubahan teknologi yang sangat pesat ini agar dapat bersaing nantinya di dalam dunia kerja sebagai imbas dari revolusi era industri 4.0 ini.

\section{Bimbingan Karir}

Bimbingan konseling adalah suatu proses pemberian bantuan kepada individu secara berkelanjutan dan sistematis, yang dilakukan oleh seorang ahli yang telah mendapat latihan khusus untuk itu, dengan tujuan agar individu dapat memahami dirinya, lingkungannya, serta dapat mengarahkan diri dan menyesuaikan diri dengan lingkungan untuk mengembangkan potensi dirinya secara optimal untuk kesejateraan dirinya dan kesejahteraan masyarakat (Angelina, 2018).

Menurut Super, bimbingan karir merupakan suatu proses untuk membantu individu (Syaodih \& Agustin, 2014) supaya dapat mengembangkan dan menerima kesatuan dan gambaran diri serta peranannya dalam dunia kerja (Sukardi, 1987). Selanjutnya, menurut National Vocational Guidance Association, bimbingan karir aalah bantuan layanan yang diberikan kepada individu untuk memilih, menyiapkan, menyesuaikan dan menetapkan dirinya dalam pekerjaan yang sesuai, serta memperoleh kebahagiaan daripadanya (Sears, 1982).

Bimbingan dan konseling karir (vocational guidance) merupakan salah satu jenis bimbingan yang berusaha membantu peserta didik dalam memecahkan masalah kariri untuk memperoleh penyesuaian diri yang sebaikbaiknya, baik pada waktu itu mapun pada masa yang akan datang. Bimbingan dan konseling karir bukan hanya memberikan bimbingan jabatan, tetapi mempunyai arti yang lebih luas, yaitu memberikan bimbingan agar peserta didik dapat memasuki kehidupan, tata hidup, dan kejadian dalam hidup, dan mepersiapkan diri dalam kehidupan sekolah menuju dunia kerja. Maka dari itu bimbingan dan konseling karir merupakan suatu program yang disusun untuk membantu perkembangan peserta didik agar ia memahami dirinya, mempelajari dunia kerja untuk mendapatkan pengalaman yang akan membantunya dalam membuat keputusan dan mendapatkan pekerjaan.

\section{Fungsi Bimbingan Karir}

Kegiatan bimbingan karir yang dilakukan diharapkan dapat memberikan berbagai informasi karir bagi individu. Harapannya yaitu siswa di sekolah akan (Sukardi, 1987):

1. Memperoleh gambaran tentang berbagai jenis pekerjaan, jabatan atau karir dimasyarakat yang dapat dimasukinya.

2. Mengetahui tentang jenis-jenis kemampuan atau keterampilan yang dituntut untuk masing-masing pekerjaan, jabatan, atau karir serta latihan yang diadakan untuk mengembangkan masing-masing kemampuan atau keterampilan tersebut. 
3. Mengetahui dan dapat menerapkan cara yang perlu ditempuh dalam memilih pekerjaan yang cocok, memperoleh pekerjaan yang telah dipilihnya baik dalam isntansi pemerintahan/swasta, dibidang kewiraswastaan, maupun mendapatkan kemudahan-kemudahan untuk memperoleh bantuan modal dan lain-lain.

\section{Tujuan Bimbingan Karir}

Secara umum tujuan bimbingan karir di sekolah adalah membantu siswa dalam pemahaman dirinya dan lingkungannya. Dalam pengambilan keputusan, perencanaan, dan pengarahan kegiatan-kegiatan yang menuju kepada karir dan cara hidup yang akan memberikan rasa kepuasan karena sesuai, serasi, dan seimbang dengan dirinya dan lingkungannya. Sedangkan secara khusus, bimbingan dan konseling karir dilaksanakan di sekolah dengan tujuan (Sukardi, 1987):

1. Agar siswa dapat meningkatkan pengetahuan tentang dirinya sendiri.

2. Agar siswa dapat meningkatkan pengetahuannya tentang dunia kerja.

3. Agar siswa dapat mengembangkan sikap dan nilai diri sendiri dalam menghadapi pilihan lapangan kerja serta dalam persiapan memasukinya.

4. Agar siswa dapat meningkatkan keterampilan berfikir agar mampu mengambil keputusan tentang jabatan yang sesuai dengan dirinya dan tersedia dalam dunia kerja.

\section{Peluang Bimbingan Karir pada Revolusi Industri 4.0}

Revolusi industri 4.0 membuka peluang yang luas bagi siapapun untuk maju. Teknologi informasi yang semakin mudah terakses hingga ke seluruh pelosok menyebabkan semua orang dapat terhubung didalam sebuah jejaring sosial. Banjir informasi seperti yang diprediksikan Futurolog Alvin Tofler (1970) menjadi realitas yang ditemukan di era revolusi industri saat ini. Informasi yang sangat melimpah ini menyediakan manfaat yang besar untuk pengembangan ilmu pengetahuan maupun perekonomian.

Jalaluddin Rakhmat (1997:6) membagi era informasi kedalam lima karakteristik, yaitu Kekayaan, Teknosfer, Infosfer, Sosiosfer, dan Psikosfer.Karakteristik informasi sebagai kekayaan menunjukkan bahwa informasi yang diterima dan dikuasai seseorang dapat dimanfaatkan untuk sarana akumulasi kekayaan atau sumber komersialisasi. Dalam konteks ini, alumni atau mahasiswa dapat mempromosikan hasil kreasinya kepada publik melalui jejaring media sosial untuk mendapatkan tanggapan atau respon sehingga dapat dijadikan ukuran untuk memperbaiki dan meningkatkan kualitas produknya. Telah banyak kisah sukses pengusahapengusaha muda atau bahkan ibu rumah tangga dalam menjalan bisnis mereka dengan memanfaatan teknologi informasi khususnya media sosial. Kunci kesuksesan mereka adalah menjual produk inovatif, menjaga kualitas dan kepercayaan konsumen, dan tentu saja kreatif.

Karakteristik informasi yang kedua adalah teknosfer atau pola lingkungan teknologi. Masyarakat di era revolusi industri 4.0 memiliki ketergantungan yang sangat besar dalam menggunakan teknologi informasi. Sebuah survey pada tahun 2014 dilakukan oleh Nokia menemukan temuan-temuan yang mengejutkan mengenai tingkat ketergantungan manusia terhadap teknologi. Pertama, rata-rata hampir setiap enam setengah menit seseorang mengecek ponselnya. Bahkan dalam waktu 16 jam saat orang beraktivitas, mereka melakukan 150 kali per hari untuk memerika ponsel mereka. Kedua, satu dari empat orang mengakui durasi onlinenya lebih banyak daripada durasi tidurnya dalam setiap harinya. Ketiga, 1.500 responden di Inggris menghabiskan waktunya dengan bermedia sosial selama 62 juta jam per hari. Keempat, perempuan lebih sering berselancar di facebook daripada laki-laki. Kelima, tingkat kecanduan terhadap media sosial seperti twitter dan facebook lebih tinggi daripada merokok. Fakta ini merupakan peluang yang dapat dimanfaatkan oleh siswa SMK untuk memasarkan produknya dengan menggunakan pasar virtual di media sosial. Saat ini pasar atau toko secara fisik tidak lagi populer. Disamping ongkos pembangunan atau sewanya mahal, pasar konvensional makin sulit dijangkau karena kepadatan lalu lintas dan mahalnya biaya transportasi.

Infosfer atau bentuk lingkungan informasi merupakan karaker ketiga dari era informasi. Daya jangkau teknologi informasi tidak hanya berskala lokal tetapi hingga skala global. Melalui internet, akses informasi dapat dijangkau hingga ke berbagai penjuru dunia. Fakta ini menjadi peluang bagi para wirausahawan muda untuk mempromosikan produk-produk kreatifnya hingga ke berbagai belahan dunia. Riset yang saya lakukan juga menguatkan hal tersebut. Meskipun skala bisnis UMKM terbilang kecil, tetapi produk-produknya dapat dinikmati oleh pasar regional berkat dukungan teknologi internet. 
Karakteristik era informasi lainnya adalah sosiosfer atau pergeseran lingkungan komunikasi sosial. Dulu para guru, kyai, ulama, pendeta, birokrat dan politisi memiliki pengaruh yang besar sebagai agen sosialisasi. Namun saat ini, peran sosialisasi tradisional mereka telah diambil alih oleh media komputer dan smarthphone. Efek ketergantungan yang tinggi dalam penggunaan media informasi digital telah membentuk opini setiap individu. Saat ini setiap orang memiliki akses yang tinggi untuk terlibat aktif untuk memberikan dan membagikan opini kepada pihak lain melalui media sosial online. Situasi ini membuka peluang bagi para mahasiswa dan alumni untuk membentuk opini positif tentang berbagai hal kepada pihak lain. Bahkan teknologi media sosial dapat dimanfaatkan untuk membentuk "keluarga besar di sekolah" di dunia virtual, walaupun secara geografis berjauhan tetapi didekatkan dengan media sosial. Hal ini menjadi peluang untuk saling bekerja sama diantara para alumni untuk berbagi informasi maupun transaksi bisnis online.

Karakteristik era informasi yang terakhir adalah psikosfer. Karakter psikosfer merupakan kemampuan seseorang untuk bertahan dalam era "banjir" informasi. Melimpahnya informasi tentunya tidak hanya membawa pengetahuan positif tetapi juga negatif. Kemampuan seseorang untuk mengolah pengetahuan (knowledge) menjadi kearifan (wisdom) dalam lingkungan sosialnya akan menentukan tingkat ketahanannya di era informasi. Dengan demikian, tindakan share and resharing informasi telah didasari oleh nilai-nilai etis sehingga tidak akan menciptakan eskalasi kegaduhan publik.

Sebagai contoh, derasnya informasi hoax (berita bohong) menjelang pilkada serentak maupun pilpres tidak akan meningkatkan kegaduhan jika penerima informasi telah memiliki kesadaran etis dalam menyaring informasi hoax. Dalam bahasa sederhananya: siswa harus memiliki pedoman etis "think first before you share". Oleh karena itu, peluang yang dapat diambil oleh peserta didik dalam konteks ini adalah dengan ikut berperan mempromosikan literasi etis untuk menggunakan media informasi secara sehat. Dalam hal ini terkait dengan bimbingan karir di sekolah memiliki peluang yang besar dengan semakin meningkatnya informasi dalam era revolusi industri 4.0. Guru BK/konselor dapat memberikan informasi-informasi yang menarik terkait dengan karir untuk memotivasi siswa mengetahui dan merencanakan arah karirnya. Selain itu, guru BK dapat menggunakan berbagai aplikasi sosial media untuk menyebarluaskan informasi terkait dengan pekerjaan, jabatan dan karir di era revolusi 4.0 ini.

\section{Tantangan Bimbingan Karir pada Revolusi Industri 4.0}

Revolusi industri generasi empat tidak hanya menyediakan peluang, tetapi juga tantangan bagi generasi milineal (Fatmawati, 2018; Marsudi \& Widjaja, 2019). Kemajuan ilmu pengetahuan dan teknologi sebagai pemicu revolusi indutri juga diikuti dengan implikasi lain seperti pengangguran, kompetisi manusia vs mesin, dan tuntutan kompetensi yang semakin tinggi.

Menurut Prof Dwikorita Karnawati, revolusi industri 4.0 dalam lima tahun mendatang akan menghapus 35 persen jenis pekerjaan. Dan bahkan pada 10 tahun yang akan datang jenis pekerjaan yang akan hilang bertambah menjadi 75 persen (Hamdan, 2018). Hal ini disebabkan pekerjaan yang diperankan oleh manusia setahap demi setahap digantikan dengan teknologi digitalisasi program. Dampaknya, proses produksi menjadi lebih cepat dikerjakan dan lebih mudah didistribusikan secara masif dengan keterlibatan manusia yang minim. Di Amerika Serikat, misalnya, dengan berkembangnya sistem online perbankan telah memudahkan proses transaksi layanan perbankan. Akibatnya, 48.000 teller bank harus menghadapi pemutusan hubungan kerja karena alasan efisiensi.

Bahkan menurut survey McKinsey, sebuah korporasi konsultan manajemen multinasional, di Indonesia sebanyak 52,6 juta lapangan pekerjaan berpotensi digantikan dengan sistem digital. Dengan kata lain, 52 persen angkatan kerja atau merepresentasikan 52,6 juta orang akan kehilangan pekerjaan.

Secara lebih detil Gambar 2 menunjukkan bahwa lapangan pekerjaan yang potensial diotomatisasikan diantaranya usaha pengolahan (manufaturing), perdagangan ritel, transportasi dan pergudangan, tenaga administrasi, konstruksi, layanan makanan dan akomodasi, pertanian, perikanan, dan kehutanan, serta layanan kesehatan dan keuangan/asuransi. Dengan demikian, revolusi industri dapat mengancam makin tingginya pengangguran di Indonesia.

Namun demikian, bidang pekerjaan yang berkaitan dengan keahlian Komputer, Matematika, Arsitektur dan Teknik akan semakin banyak dibutuhkan. Bidang-bidang keahlian ini diproyeksikan sesuai dengan tuntutan pekerjaan yang mengandalkan teknologi digital.

Situasi pergeseran tenaga kerja manusia ke arah digitalisasi merupakan bentuk tantangan yang perlu direspon oleh para peserta didik. Tantangan ini perlu dijawab dengan peningkatan kompetensi siswa terutama penguasaan teknologi komputer, keterampilan berkomunikasi, kemampuan bekerjasama secara kolaboratif, dan 
kemampuan untuk terus belajar dan adaptif terhadap perubahan lingkungan. Berkaitan dengan peran bimbingan karir menjadi tantangan bagi setiap guru BK/Konselor untuk mempunyai keterampilan digital, melek teknologi, menguasai berbagai teknologi untuk mensosialisasikan tentang informasi-informasi karir terhadap para peserta didik.

\section{KESIMPULAN}

Revolusi industri saat ini memasuki fase keempat. Perkembangan ilmu pengetahuan dan teknologi yang sangat pesat memberikan dampak yang besar terhadap kehidupan manusia. Banyak kemudahan dan inovasi yang diperoleh dengan adanya dukungan teknologi digital. Layanan menjadi lebih cepat dan efisien serta memiliki jangkauan koneksi yang lebih luas dengan sistem online. Hidup menjadi lebih mudah dan murah.

Namun demikian, digitalisasi program juga membawa dampak negatif. Peran manusia setahap demi setahap diambil alih oleh mesin otomatis. Akibatnya, jumlah pengangguran semakin meningkat. Hal ini tentu saja akan menambah beban masalah lokal maupun nasional. Oleh karena itu, guru BK/Konselor dalam era revolusi industri 4.0 ini semestinya dapat kreatif untuk memanfaatkan peluang agar dapat mensosialisasikan dan mengeksiskan peranan layanan bimbingan dan konseling khususnya bimbingan karir di sekolah. Sehingga tantangan tersebut dapat dijalankan oleh guru BK/konselor dan kinerjanya dapat terlaksana secara optimal.

\section{REFERENSI}

Angelina, P. R. (2018). Optimalisasi Bimbingan dan Konseling Karir di Era Revolusi Industri 4.0. Prosiding SNTP, 1.

Anshori, A. G. (2018). Perbankan syariah di Indonesia: UGM PRESS.

Fadli, R. P., Alizamar, A., \& Afdal, A. (2017). Persepsi Siswa tentang Kesesuaian Perencanaan Arah Karir Berdasarkan Pilihan Keahlian Siswa Sekolah Menengah Kejuruan. Konselor, 6(2), 74-82.

Fatmawati, E. (2018). Disruptif diri pustakawan dalam menghadapi era revolusi industri 4.0.

Gibson, R. L., \& Mitchell, M. H. (2011). Bimbingan dan Bimbingan dan konseling, edisi Bahasa Indonesia. Yogyakarta: Pustaka Pelajar.

Hakim, A. (2010). Model pengembangan kewirausahaan sekolah menengah kejuruan (smk) dalam menciptakan kemandirian sekolah. Jurnal, 4(1).

Hamdan, H. (2018). Industri 4.0: Pengaruh Revolusi Industri Pada Kewirausahaan Demi Kemandirian Ekonomi. Jurnal Nusantara Aplikasi Manajemen Bisnis, 3(2), 1-8.

Hermann, M., Pentek, T., \& Otto, B. (2016). Design principles for industrie 4.0 scenarios. Paper presented at the System Sciences (HICSS), 2016 49th Hawaii International Conference on.

Indonesia, P. R. (2003). Undang-undang Republik Indonesia nomor 20 tahun 2003 tentang sistem pendidikan nasional. Jakarta: Pemerintah Republik Indonesia.

Jasperneite, J. (2012). Was hinter Begriffen wie Industrie 4.0 steckt. Computer \& Automation, 19.

Juwitaningrum, I. (2013). Program bimbingan karir untuk meningkatkan kematangan karir siswa SMK. PSIKOPEDAGOGIA Jurnal Bimbingan dan Konseling, 2(2), 132-147.

Kagermann, H., Helbig, J., Hellinger, A., \& Wahlster, W. (2013). Recommendations for implementing the strategic initiative INDUSTRIE 4.0: Securing the future of German manufacturing industry; final report of the Industrie 4.0 Working Group: Forschungsunion.

Lasi, H., Fettke, P., Kemper, H.-G., Feld, T., \& Hoffmann, M. (2014). Industry 4.0. Business \& Information Systems Engineering, 6(4), 239-242.

Marsudi, A. S., \& Widjaja, Y. (2019). Industri 4.0 Dan Dampaknya Terhadap Financial Technology Serta Kesiapan Tenaga Kerja Di Indonesia. Ikra-Ith Ekonomika, 2(2), 1-10.

Marwiyah, S. (2012). Konsep pendidikan berbasis kecakapan hidup. Jurnal Falasifa, 3(1). 
Maryati, S. (2015). Dinamika pengangguran terdidik: tantangan menuju bonus demografi di Indonesia. JURNAL ECONOMICA: Research of Economic And Economic Education, 3(2), 124-136.

Muhammad, Y. (2018). Era Industri 4.0: Tantangan dan Peluang Perkembangan Pendidikan Kejuruan Indonesia.

Nofrion, N. (2018). Pentingnya Keterampilan Komunikasi di Era Revolusi Industri 4.0.

Schwab, K. (2017). The fourth industrial revolution: Crown Business.

Sears, S. (1982). A definition of career guidance terms: A National Vocational Guidance Association perspective. Vocational Guidance Quarterly, 31(2), 137-143.

Sukardi, D. K. (1987). Bimbingan karir di sekolah-sekolah. Jakarta: Ghalia Indonesia.

Supardi, U. (2015). Arah pendidikan di Indonesia dalam tataran kebijakan dan implementasi. Formatif: Jurnal Ilmiah Pendidikan MIPA, 2(2).

Syaodih, E., \& Agustin, M. (2014). Bimbingan Konseling untuk Anak Usia Dini.

Wibowo, N. (2016). Upaya Memperkecil Kesenjangan Kompetensi Lulusan Sekolah Menengah Kejuruan dengan Tuntutan Dunia Industri. Jurnal Pendidikan Teknologi dan Kejuruan, 23(1), 45-59. 